
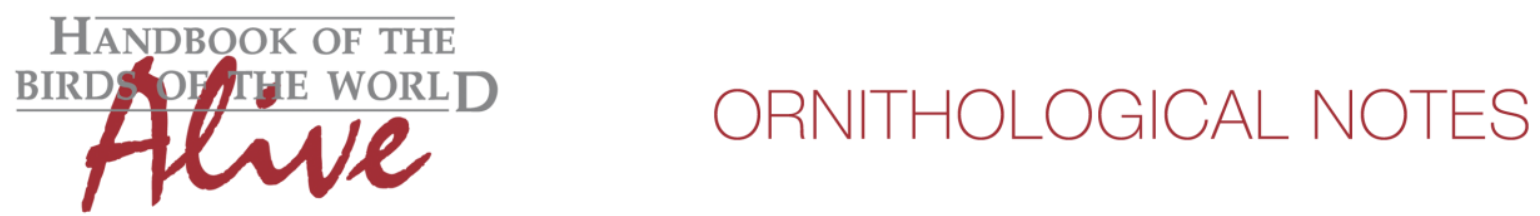

\title{
Notes on the vocalizations of Black-chinned Antbird (Hypocnemoides melanopogon) and Band-tailed Antbird (Hypocnemoides maculicauda).
}

Peter Boesman

In the following we briefly analyze and compare voice of Black-chinned Antbird

(Hypocnemoides melanopogon) and Band-tailed Antbird (Hypocnemoides maculicauda). We also try to quantify the extent of any vocal differences using the criteria proposed by Tobias et al. (2010), as a support for taxonomic review. We have made use of sound recordings available on-line from Xeno Canto (XC).

Black-chinned Antbird (Hypocnemoides melanopogon) and Band-tailed Antbird (Hypocnemoides maculicauda) have long been considered separate species, but reasons therefore are generally considered rather weak (Zimmer 2003), and a comparative vocal analysis has apparently never been carried out.

Loudsong of both species is similar but shows a number of clear and very constant differences, for which they can be separated easily (Fig. 1):

loudsong of Black-chinned Antbird is a series of notes, initially rising than falling and (only) slightly accelerating. End notes occasionally slightly buzzy (probably when excited), but never drawn-out.

loudsong of Band-tailed Antbird is a long series of notes, initially rising and accelerating a lot, then dropping and ending in several long scratchy notes.

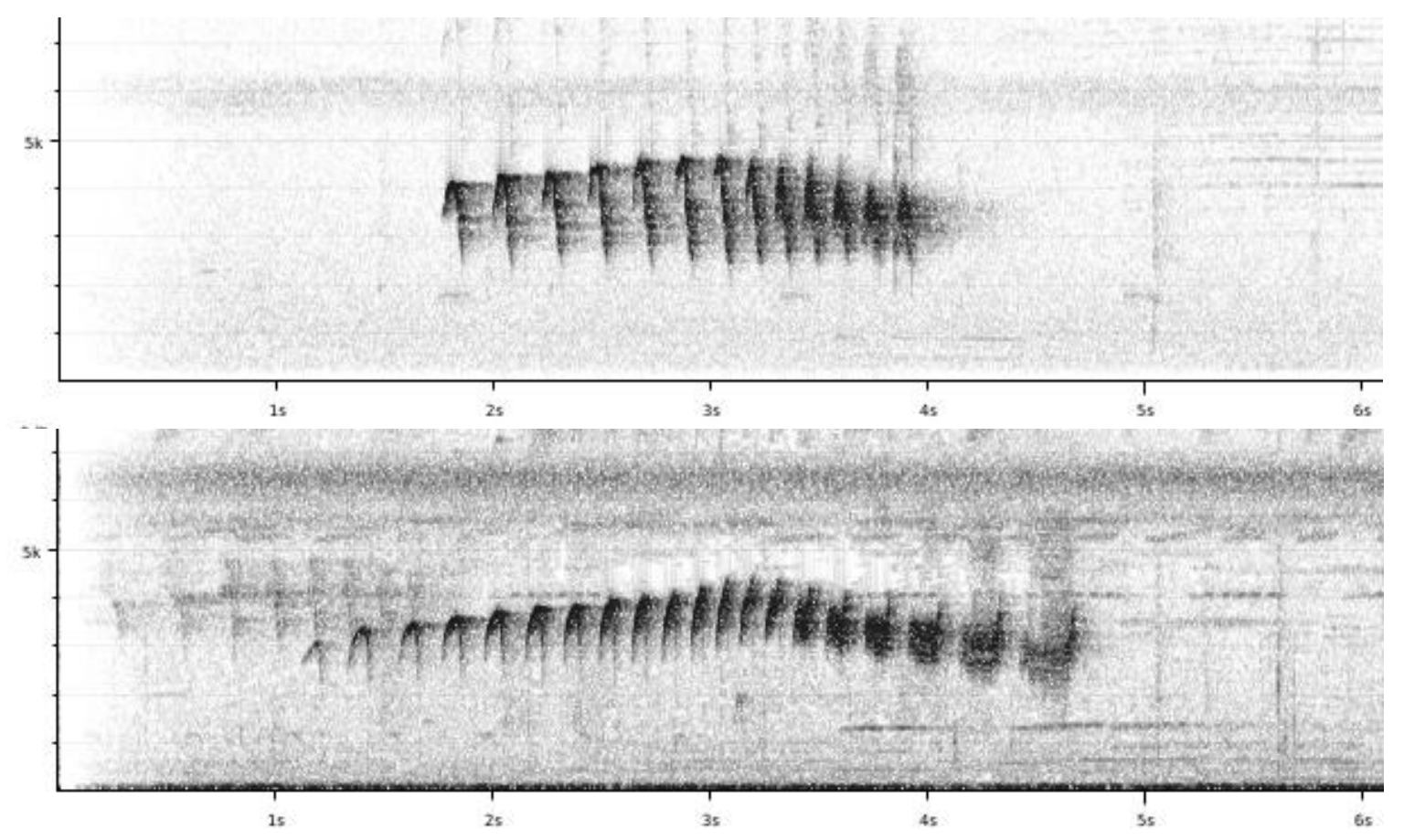

Figure 1: top to bottom: Typical loudsong of Black-chinned Antbird and Band-tailed Antbird 

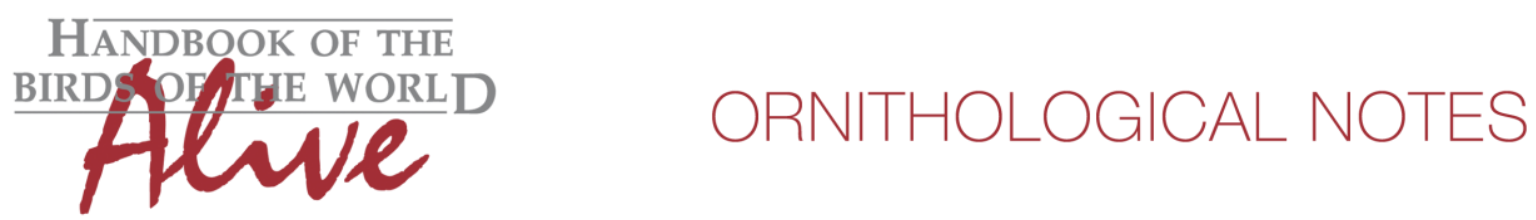

We obtained the following measurements ( $n=10$ for both):

$\begin{array}{ll}\text { Hypocnemoides melanopogon } \\ \text { \# notes } & 10-19 \\ \text { total length } & 1.8-2.4 \mathrm{~s} \\ \text { max. pitch } & 3850-4550 \mathrm{~Hz} \\ \text { fastest pace } & 0.105-0.15 \\ \text { longest note } & 0.086-0.12 \mathrm{~s}\end{array}$

Hypocnemoides maculicauda

\# notes $19-34$

total length $\quad 3.6-5.3 \mathrm{~s}$

max. pitch $4000-5000 \mathrm{~Hz}$

fastest pace $\quad 0.07-0.12$

longest note $\quad 0.2-0.47 \mathrm{~s}$ (the long scratchy notes at end, which are always present)

Main measured differences are thus length of song (score 2-3), length of longest note (score 2-3), number of notes (score 2 ) and maculicauda has a slightly faster acceleration and reaches on average slightly higher frequencies. Also note shape of central and ending notes is quite different.

-> total score about 5

These differences are very constant over the entire range of both species.

This note was finalized on 8th May 2015, using sound recordings available on-line at that moment. We would like to thank in particular the many sound recordists who placed their recordings for these species on XC.

\section{References}

Tobias, J.A., Seddon, N., Spottiswoode, C.N., Pilgrim, J.D., Fishpool, L.D.C. \& Collar, N.J. (2010). Quantitative criteria for species delimitation. Ibis 152(4): 724-746.

Zimmer, K. and M. Isler (2003). Family Thamnophilidae (typical antbirds). Pages 448-681 in J. del Hoyo, A. Elliot, and D. A. Christie, editors. Handbook of the Birds of the World. Vol. 8. Broadbills to Tapaculos. Lynx Edicions, Barcelona.

\section{Recommended citation}

Boesman, P. (2016). Notes on the vocalizations of Black-chinned Antbird (Hypocnemoides melanopogon) and Band-tailed Antbird (Hypocnemoides maculicauda). HBW Alive Ornithological Note 61. In: Handbook of the Birds of the World Alive. Lynx Edicions, Barcelona. (retrieved from http://www.hbw.com/node/931944 on 14 May 2016). 